This item was submitted to Loughborough's Research Repository by the author.

Items in Figshare are protected by copyright, with all rights reserved, unless otherwise indicated.

\title{
Evolution of the hardness and Young's moduli of interlayers in Sn99Cu1/Cu solder joints subjected to isothermal ageing
}

PLEASE CITE THE PUBLISHED VERSION

https://doi.org/10.1007/s10854-017-7680-1

\section{PUBLISHER}

(c) Springer Nature

\section{VERSION}

AM (Accepted Manuscript)

\section{PUBLISHER STATEMENT}

This work is made available according to the conditions of the Creative Commons Attribution-NonCommercialNoDerivatives 4.0 International (CC BY-NC-ND 4.0) licence. Full details of this licence are available at: https://creativecommons.org/licenses/by-nc-nd/4.0/

\section{LICENCE}

CC BY-NC-ND 4.0

\section{REPOSITORY RECORD}

Chen, Zhiwen, Changqing Liu, Bing An, Yiping Wu, and Li Liu. 2019. "Evolution of the Hardness and Young's Moduli of Interlayers in Sn99cu1/cu Solder Joints Subjected to Isothermal Ageing". figshare. https://hdl.handle.net/2134/36625. 


\title{
Evolution of the hardness and Young's moduli of interlayers in
}

\section{Sn99Cu1/Cu solder joints subjected to isothermal ageing}

\author{
Zhiwen $\mathrm{Chen}^{2}$, Changqing $\mathrm{Liu}^{2}$, Bing $\mathrm{An}^{3}$, Yiping $\mathrm{Wu}^{3}, \mathrm{Li} \mathrm{Liu}{ }^{1,4 *}$ \\ 1. Wuhan University of Technology, 122 Luoshi Road, Wuhan, Hubei, P.R.China \\ 2. Loughborough University, Loughborough, Leicestershire, UK, LE11 3TU \\ 3. Huazhong University of Science and Technology, 1037 Luoyu Road, Wuhan, Hubei, P.R. China \\ 4. State Key Laboratory of Materials Processing and Die \& Mould Technology, Huazhong University of \\ Science and Technology, 1037 Luoyu Road, Wuhan 430074, Hubei, China \\ 1.liu@whut.edu.cn
}

\begin{abstract}
The interlayers at solder/pad interface are critical to the reliability of solder joints; hence, their mechanical properties is of vital importance. However, the correlation between service duration and evolution of mechanical characteristics of these interlayers has seldom been reported. In this work, hardness and Young's moduli of $\mathrm{Cu}_{6} \mathrm{Sn}_{5}, \mathrm{Cu}_{3} \mathrm{Sn}$ and $\mathrm{Cu}$ were evaluated by nanoindenation after ageing for every $100 \mathrm{~h}$ up to $500 \mathrm{~h}$. It was found that hardness and Young's moduli of $\mathrm{Cu}_{6} \mathrm{Sn}_{5}$ and $\mathrm{Cu}_{3} \mathrm{Sn}$ dropped with aging and reached the bottom at $200 \mathrm{~h}$ and $300 \mathrm{~h}$, respectively, followed by a gradual increase. This $U$-shape curve was generally opposite to the evolution of corresponding parameters in $\mathrm{Cu}$. Evolution of mechanical properties of IMCs can be attributed to constrained volume shrinkage induced by solid-state reactions that producing IMCs. The resultant stress ultimately affected load-displacement curves recorded by nanoindentation tests. The observed reverse evolution trend of examined parameters of $\mathrm{Cu}$ and adjacent IMC layers was a result of mutual constraint posed by $\mathrm{Cu}_{3} \mathrm{Sn} / \mathrm{Cu}$ interface.
\end{abstract}

Keywords: lead-free solder joint, IMC layers, nano-indentation, mechanical properties, volume shrinkage 


\section{Introduction}

During reflow, intermetallic compounds (IMCs) that form at interfaces between solder alloys and their bonding pads provide mechanical and electrical interconnects in electronic packages. However, excessive growth of IMCs during reflow and subsequent ageing deteriorate the integrity of solder joints and hence reliability of electronic packages $[1,2]$. In particular, for Sn-based solder joints, fractures in thick interfacial IMC layer are the primary failure mode in drop tests $[3,4]$. Because of the close relationship between mechanical properties of IMCs and the reliability of electronic devices, characterizing mechanical properties of IMCs in macromechanical and nanomechanical regimes is of vital importance.

The thickness of IMC layer at solder/pad interface is normally at microscale, which poses substantial challenges in characterizing mechanical properties of IMC layers. Among various test technologies, nanoindentation is one of the most viable ways to evaluate mechanical properties of microstructures at microscale [5]. Generally, higher hardness indicates higher mechanical strength [6]. Therefore, some studies have been performed on thick IMC layers (approximately $20 \mu \mathrm{m}$ ) after long reflow or ageing times using nanoindentation to derive their Young's moduli and hardness [7]. Effects of strain rate and gain orientations on indentation results have also been reported $[8,9]$. However, limited works were focused on potential effects of prolonged service durations on the evolution of mechanical properties of $\mathrm{Cu}-\mathrm{Sn} \mathrm{IMC}$ layers at solder/pad interface.

In this paper, a $\mathrm{Sn} 99 \mathrm{Cu} 1 / \mathrm{Cu}$ solder joint was aged at $175^{\circ} \mathrm{C}$ from $0 \mathrm{~h}$ to $500 \mathrm{~h}$. The evolution of microhardness and Young's moduli of interlayers at $\mathrm{Sn} 99 \mathrm{Cu} 1 / \mathrm{Cu}$ interface, including $\mathrm{Cu}_{6} \mathrm{Sn}_{5}$ layer, $\mathrm{Cu}_{3} \mathrm{Sn}$ layer and $\mathrm{Cu}$ substrate, was investigated by nanoindentation after ageing for different durations.

\section{Experimental details}

For sample preparation, Sn99Cu1 solder was reflowed on polycrystalline $\mathrm{Cu}$ sheet (purity: 99.9 wt.\%) at a peak temperature of $270^{\circ} \mathrm{C}$ for $2 \mathrm{~min}$. Specimens were then stored in a vacuum oven at $175^{\circ} \mathrm{C}$ for 0 to 500 hours. After every $100 \mathrm{~h}$ of ageing, specimens were removed, ground and polished using $0.05 \mu \mathrm{m}$ colloidal silica to expose their interfacial microstructure and IMC layers. During sample preparation, no mounting was employed to avoid any potential effects caused by the contraction of resin. Nanoindentation tests were subsequently conducted on $\mathrm{Cu}_{6} \mathrm{Sn}_{5}$ layer, $\mathrm{Cu}_{3} \mathrm{Sn}$ layer and $\mathrm{Cu}$ substrate (illustrated in Fig. 1) using a NanoTest Platform3 system. Seven indentation tests were carried out on each type of IMC with a horizontal interval of $20 \mu \mathrm{m}$. The drift rate of the test system was calibrated to be less than $0.05 \mathrm{~nm} / \mathrm{s}$ prior to testing. A Vickers indenter was used at ambient temperature. 


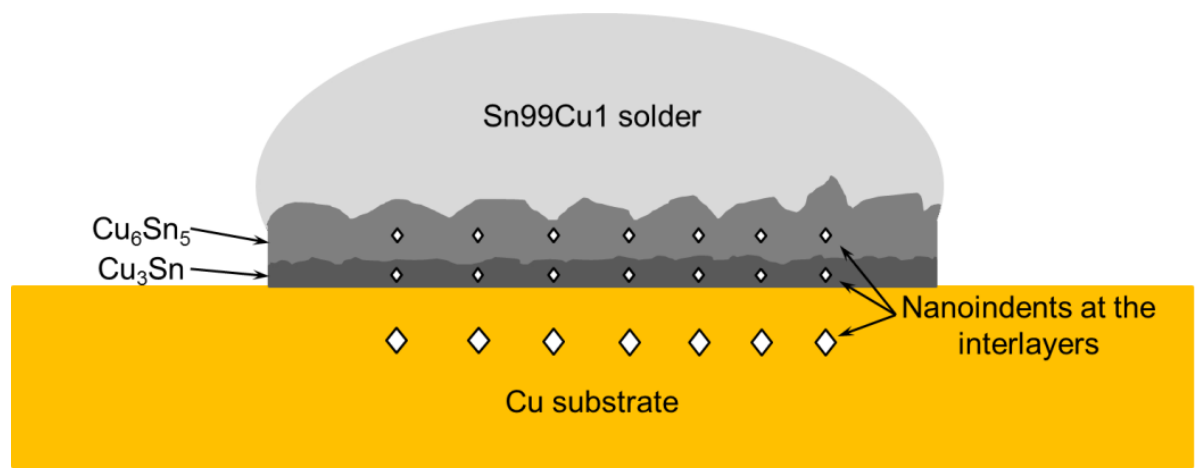

Fig. 1 Schematic of designated locations for nanoindents in solder joints.

Parameters of nanoindentation tests at each layer are listed in Table 1. Initial loads, loading rates, maximum loads, unloading rates, dwelling periods and termination criteria for each test on different interlayers were set to be identical for comparison. Nominal strain rates for different interlayers was set between 0.03 and $0.04 \mathrm{~s}^{-1}$, so that effect of strain rate on measured hardness was minimized [10]. Dwell periods at maximum load were set to zero to avoid effects of any possible creep on measured depth of indents [11]. Because of the micro-scale thickness of interfacial $\mathrm{Cu}_{6} \mathrm{Sn}_{5}$ and $\mathrm{Cu}_{3} \mathrm{Sn}$ layers, depth of indents within interfacial IMC layers was set to $0.3 \mu \mathrm{m}$, so that nanoindents were within one specific IMC layer without interacting with adjacent material. Similarly, nanoindents in $\mathrm{Cu}$ were located approximately $10 \mu \mathrm{m}$ from $\mathrm{Cu}_{3} \mathrm{Sn} / \mathrm{Cu}$ interface so that pile-up or sinking-in of $\mathrm{Cu}$ was accommodated within $\mathrm{Cu}$ portion during testing. Furthermore, in $\mathrm{Sn} 99 \mathrm{Cu} 1 / \mathrm{Cu}$ solder joint immediately after reflowing, $\mathrm{Cu}_{6} \mathrm{Sn}_{5}$ and $\mathrm{Cu}_{3} \mathrm{Sn}$ layers are not visible under the microscope in NanoTest Platform3. Therefore, tests on $\mathrm{Cu}_{6} \mathrm{Sn}_{5}$ and $\mathrm{Cu}_{3} \mathrm{Sn}$ layers started from solder joints aged at $175^{\circ} \mathrm{C}$ for $100 \mathrm{~h}$.

Table 1 Parameters and settings for nanoindentation tests.

\begin{tabular}{|c|c|c|c|c|}
\hline Specimen & Maximum Depth & Termination & Loading rate & Unloading rate \\
\hline $\mathrm{Cu}$ & $1 \mu \mathrm{m}$ & Depth control & $1 \mathrm{mN} / \mathrm{s}$ & $1 \mathrm{mN} / \mathrm{s}$ \\
\hline $\mathrm{Cu}_{6} \mathrm{Sn}_{5}$ & $0.3 \mu \mathrm{m}$ & Depth control & $0.2 \mathrm{mN} / \mathrm{s}$ & $0.2 \mathrm{mN} / \mathrm{s}$ \\
\hline $\mathrm{Cu}_{3} \mathrm{Sn}$ & $0.3 \mu \mathrm{m}$ & Depth control & $0.4 \mathrm{mN} / \mathrm{s}$ & $0.4 \mathrm{mN} / \mathrm{s}$ \\
\hline
\end{tabular}

After nanoindentation tests, hardness of each interlayer after various ageing durations was derived from corresponding load-displacement curves using the software provided with NanoTest Platform3. The hardness of specimens, $H$, is defined as the average stress within contact area [12]:

$$
H=F / A
$$

where $H$ is measured hardness, $F$ is maximum force applied in nanoindentation test, and $A$ is projected contact area of indents. Among the variables, $F$ is directly recorded by the instrument, and $A$ can be derived from the 
contact area-depth correlation of indenter.

In nanoindentation, reduced modulus $\left(E_{r}\right)$ that accounts for the deformation of both specimen and indenter is defined as [13]:

$$
E_{r}=\frac{1}{\beta} \frac{\sqrt{\pi}}{2} \frac{S}{\sqrt{A_{C}}}
$$

where $\beta$ is a constant with a value of 1.012 for Vickers indenter used in these tests; $\mathrm{S}=\frac{d P}{d h}$, is contact stiffness which is defined as the slope of upper portion of unloading data; $A_{C}$ is contact area, which can be derived from the shape function of Vickers indenter. Young's modulus of tested materials is related to reduced modulus by [14]:

$$
\frac{1}{E_{r}}=\frac{1-v^{2}}{E}+\frac{1-v_{i}^{2}}{E_{i}}
$$

Where $E$ and $v$ are Young's modulus and Poisson's ratio of tested materials, while $E_{i}$ and $v_{i}$ are Young's modulus and Poisson's ratio of used indenter.

Because of the microscale depth of nanoindents in interlayers, possible effects of surface roughness on tests were also evaluated. After tests, indents in $\mathrm{Cu}, \mathrm{Cu}_{6} \mathrm{Sn}_{5}$ and $\mathrm{Cu}_{3} \mathrm{Sn}$ layers were profiled using a surface metrology instrument (Alicona Infinite Focus) with a vertical resolution of $10 \mathrm{~nm}$. Therefore, influence of surface roughness of samples on indentation tests can be estimated.

\section{Results}

\subsection{Nanoindentation}

Fig. 2 a), c) and e) show representative nanoindents within $\mathrm{Cu}$ and interfacial $\mathrm{Cu}_{6} \mathrm{Sn}_{5}$ and $\mathrm{Cu}_{3} \mathrm{Sn}$ layers. It is shown that nanoindents are located at the designated positions discussed in section 2. Fig. 2b), d) and f) show 3D models of typical indents in corresponding layers constructed from Alicona surface profiling results of nanoindents. 

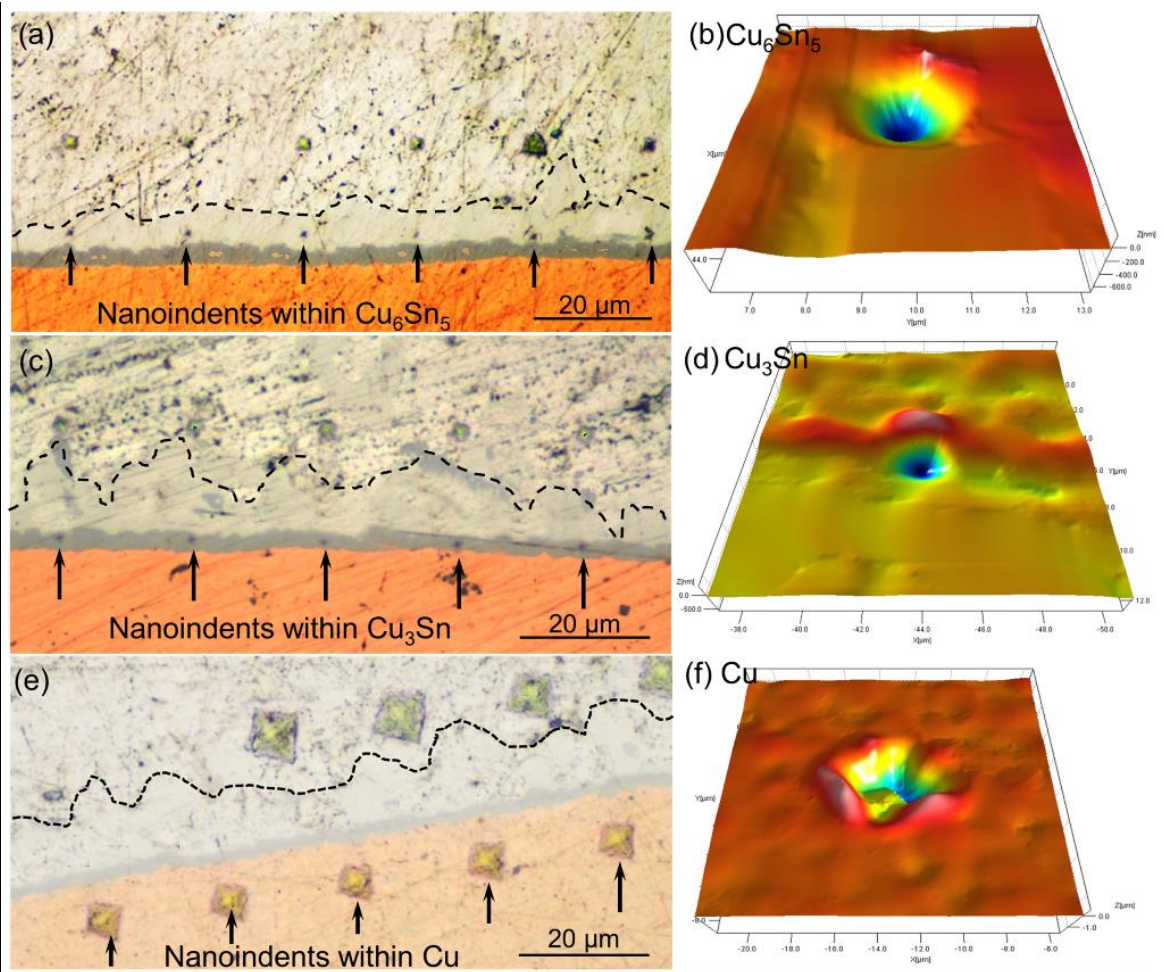

Fig. 2 Nanoindents in (a) $\mathrm{Cu}_{6} \mathrm{Sn}_{5}$ layer, (c) $\mathrm{Cu}_{3} \mathrm{Sn}$ layer and (e) $\mathrm{Cu}$ substrate. Sub-figures (b), (d), (f) show the respective 3D profiles of indents in corresponding layers.

Because of the microscale size of nanoindents, potential influence of surface roughness of samples on nanoindentation tests was also evaluated on the basis of surface profiling results from Alicona system, with particular attention on the comparison between indentation depth and surface roughness. Profiles across the centre of nanoindents in Fig. 2 (b), (d) and (f) are extracted and illustrated in Fig. 3. It shows that the average surface roughness of sample surface was approximately $20 \mathrm{~nm}$. Compared with the depth of nanoindents (300 $\mathrm{nm}$ to 1000 $\mathrm{nm})$, it is reasonable to conclude that effect of surface roughness on nanoindentation tests was minimal. 

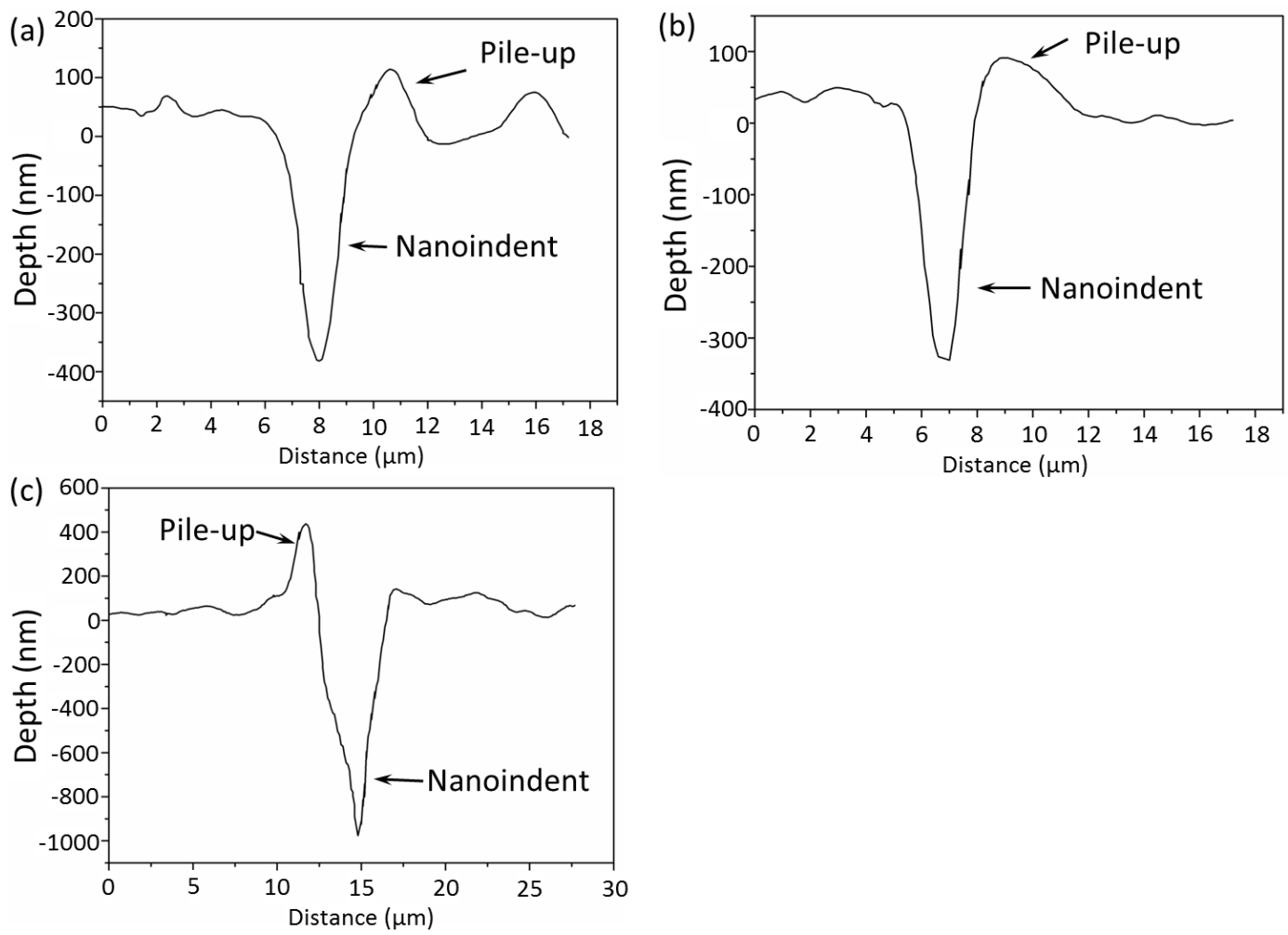

Fig. 3 Surface profiles across the centre of nanoindents within (a) $\mathrm{Cu}_{6} \mathrm{Sn}_{5}$ layer, (b) $\mathrm{Cu}_{3} \mathrm{Sn}$ layer and (c) $\mathrm{Cu}$ substrate.

After nanoindentation tests, load-displacement curves were extracted. Average maximum load from the nanoindents in $\mathrm{Cu}_{6} \mathrm{Sn}_{5}$ layer is $7.4 \mathrm{mN}$, and those from indents in $\mathrm{Cu}_{3} \mathrm{Sn}$ and $\mathrm{Cu}$ are $10.0 \mathrm{mN}$ and $34.5 \mathrm{mN}$, respectively. Example curves of nano indents from $\mathrm{Cu}_{6} \mathrm{Sn}_{5}, \mathrm{Cu}_{3} \mathrm{Sn}$ and $\mathrm{Cu}$ are illustrated in Fig. 4.

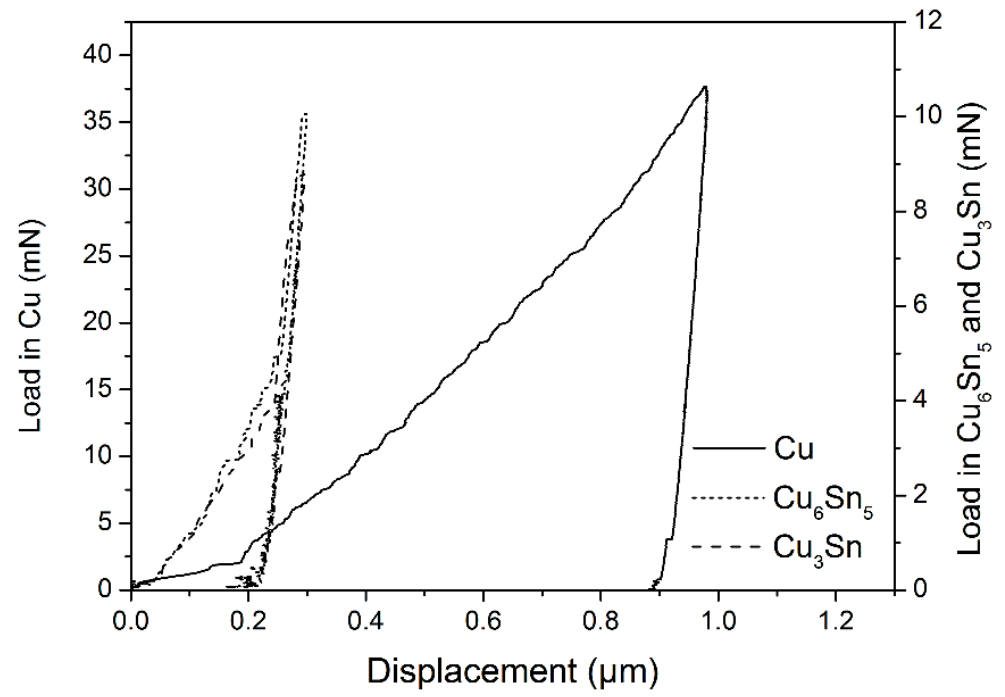

Fig. 4 Representative load-displacement curves from nanoindents in $\mathrm{Cu}_{6} \mathrm{Sn}_{5}$ layer, $\mathrm{Cu}_{3} \mathrm{Sn}$ layer and $\mathrm{Cu}$ substrate. 


\subsection{Evolution of hardness and Young's modulus}

After indentation testing, hardness of $\mathrm{Cu}_{3} \mathrm{Sn}, \mathrm{Cu}_{6} \mathrm{Sn}_{5}$ and $\mathrm{Cu}$ after ageing is evaluated using the analysis software in the instrument. Summary of hardness in different layers after prolonged aging are illustrated in Fig. 5. It is shown that hardness-duration curves for $\mathrm{Cu}_{6} \mathrm{Sn}_{5}$ and $\mathrm{Cu}_{3} \mathrm{Sn}$ have a similar $U$ shape. They reached their minimum values, $4.0 \mathrm{GPa}$ and $4.5 \mathrm{GPa}$, at $200 \mathrm{~h}$ and $300 \mathrm{~h}$, respectively. And the average hardness are $5.9 \pm 1.1$ $\mathrm{GPa}$ for $\mathrm{Cu}_{3} \mathrm{Sn}$ and $4.9 \pm 1.8 \mathrm{GPa}$ for $\mathrm{Cu}_{6} \mathrm{Sn}_{5}$. In contrast, hardness of $\mathrm{Cu}$ was within a small range from $1.5 \mathrm{GPa}$ to $1.8 \mathrm{GPa}$, as illustrated in Fig. 5 (c). It peaked after approximately $200 \mathrm{~h}$ of ageing, followed by a gradual decrease.
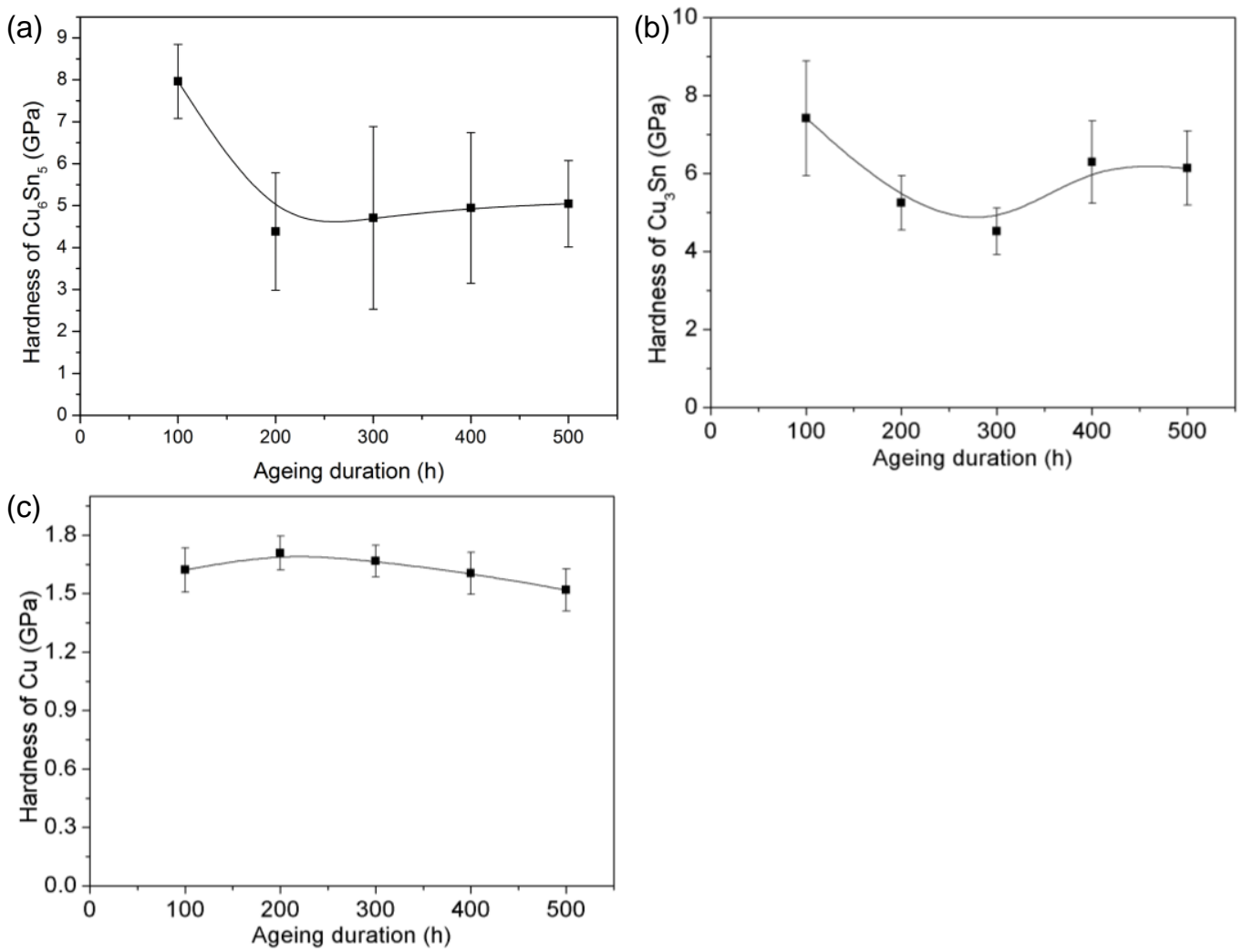

Fig. 5 Evolution of hardness within (a) $\mathrm{Cu}_{6} \mathrm{Sn}_{5}$ layer, (b) $\mathrm{Cu}_{3} \mathrm{Sn}$ layer and (c) $\mathrm{Cu}$ substrate.

Table 2 lists average hardness of each layer after throughout aging. In general, these results show close agreement with reported values in literatures $[7,15]$. It is worth of notice that deviation in hardness of $\mathrm{Cu}_{6} \mathrm{Sn}_{5}$ is higher than that of $\mathrm{Cu}_{3} \mathrm{Sn}$, which is a result of different grain sizes of these two phases and influence of grain orientations. It has been reported that $\mathrm{Cu}_{6} \mathrm{Sn}_{5}$ grains are generally several times bigger than those of $\mathrm{Cu}_{3} \mathrm{Sn}$ after ageing [9]. Therefore, nanoindentation on $\mathrm{Cu}_{6} \mathrm{Sn}_{5}$ is highly likely to be in one single grain in each test, and different grain orientations of tested grains can pose significant effect on test results. For $\mathrm{Cu}_{3} \mathrm{Sn}$ phase, several grains can be involved in one test, which can average out the influence from grain orientations. 
Table 2 Comparison between the hardness obtained in this work and reported results.

\begin{tabular}{ccc}
\hline & Average hardness after ageing $(\mathrm{GPa})$ & Reported hardness (GPa) \\
\hline $\mathrm{Cu}_{6} \mathrm{Sn}_{5}$ & $4.9 \pm 1.8$ & $6.1 \pm 0.5[7]$ \\
$\mathrm{Cu}_{3} \mathrm{Sn}$ & $5.9 \pm 1.1$ & $5.7 \pm 0.6[7]$ \\
$\mathrm{Cu}$ & $1.6 \pm 0.1$ & $2.2 \pm 0.2[7]$ \\
\hline
\end{tabular}

Evolution of Young's moduli of $\mathrm{Cu}_{3} \mathrm{Sn}, \mathrm{Cu}_{6} \mathrm{Sn}_{5}$ and $\mathrm{Cu}$ after prolonged ageing is illustrated in Fig. 6. The Young's modulus-duration curve for $\mathrm{Cu}_{6} \mathrm{Sn}_{5}$ layer was generally in $U$-shape, with a valley of $60 \mathrm{GPa}$ at $200 \mathrm{~h}$. In the case of $\mathrm{Cu}_{3} \mathrm{Sn}$ layer, a similar shape of curve can be identified and measured Young's modulus fluctuates between 134 and $155 \mathrm{GPa}$. By contrast, Young's modulus of $\mathrm{Cu}$ increased from $126 \mathrm{GPa}$ at $100 \mathrm{~h}$ to $167 \mathrm{GPa}$ at $200 \mathrm{~h}$ and remained relatively stable within the range of 142-158 GPa thereafter.
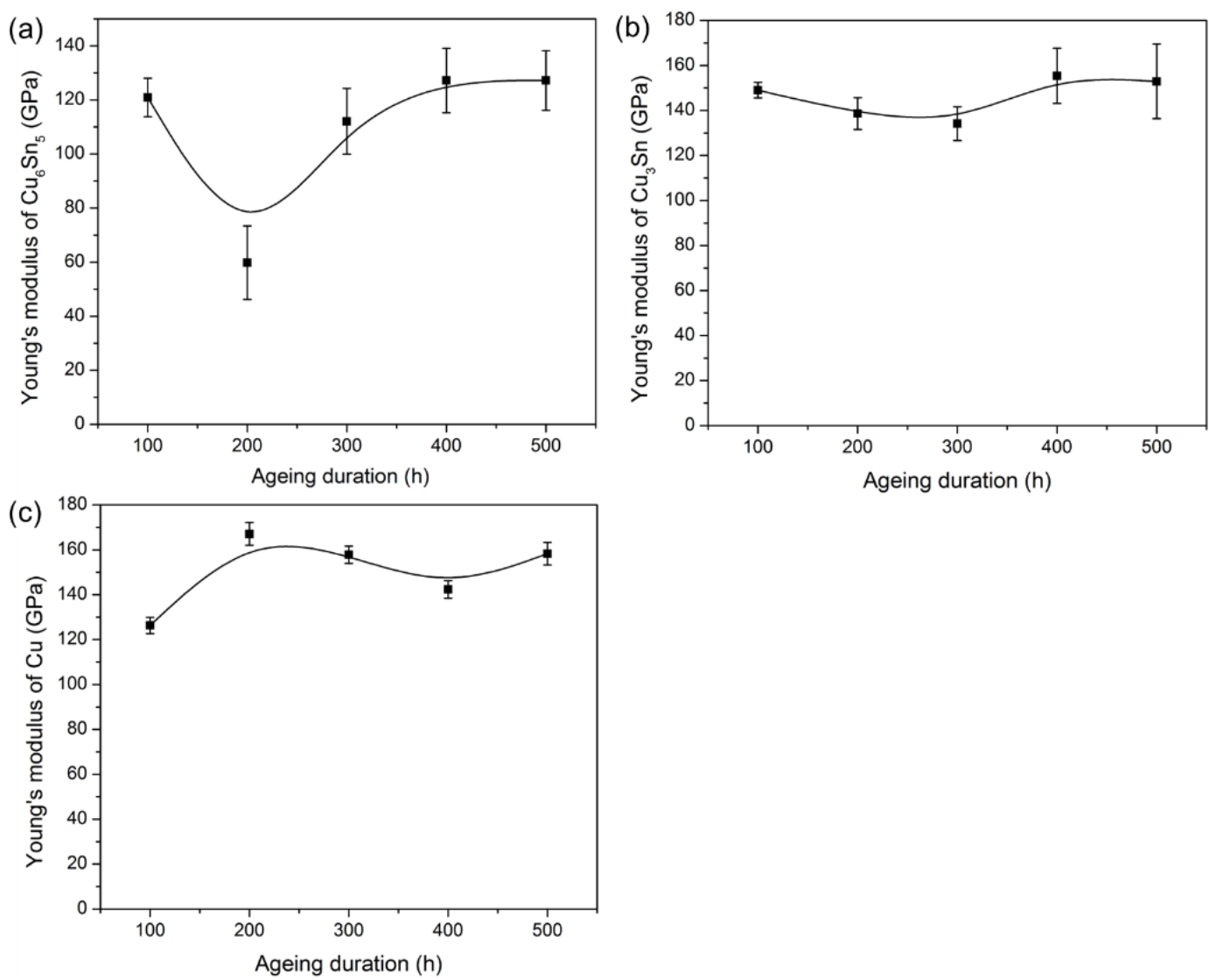

Fig. 6 Evolution of Young's moduli within (a) $\mathrm{Cu}_{6} \mathrm{Sn}_{5}$ layer, (b) $\mathrm{Cu}_{3} \mathrm{Sn}$ layer and (c) Cu substrate.

Average Young's moduli of $\mathrm{Cu}_{6} \mathrm{Sn}_{5}, \mathrm{Cu}_{3} \mathrm{Sn}$ and $\mathrm{Cu}$ after ageing are listed in Table 3. Experimental results from this work reasonably conforms with reported results $[7,15]$. Higher variation in Young's modulus of $\mathrm{Cu}_{6} \mathrm{Sn}_{5}$ is resulting from the effect of grain orientations in different tests [9]. 
Table 3 Comparison between Young's moduli in this work and reported results.

\begin{tabular}{ccc}
\hline & Average E after ageing $(\mathrm{GPa})$ & Reported E (GPa) \\
\hline $\mathrm{Cu}_{6} \mathrm{Sn}_{5}$ & $109 \pm 28$ & $125 \pm 7[7]$ \\
$\mathrm{Cu}_{3} \mathrm{Sn}$ & $146 \pm 9$ & $136 \pm 6[7]$ \\
$\mathrm{Cu}$ & $150 \pm 16$ & $111 \pm 4[7]$ \\
\hline
\end{tabular}

\section{Discussion}

In Fig. 5 and Fig. 6, it can be found that hardness and Young's moduli of $\mathrm{Cu}_{6} \mathrm{Sn}_{5}$ layer and $\mathrm{Cu}_{3} \mathrm{Sn}$ layer evolved along a similar trend, which is opposite to the trend for $\mathrm{Cu}$. It has been reported that changes in hardness are closely related to stress state of a material [16-18]. For a stressed specimen, the applied maximum load $(F)$ should follow the relationship $F_{\text {compression }}>F_{\text {stress free }}>F_{\text {tension }}$ [19-22] at the same indentation depth, because the stress that acts as an additive load to resist penetration of an indenter into specimen varies with stress state within sample. Consequently, stress state can affect measured hardness of samples in nanoindentation tests. And a decrease in hardness indicates ascension of tensile stress within specimen.

From literatures, a volume shrinkage can be induced by solid-state reactions between $\mathrm{Cu}$ and $\mathrm{Sn}$ because of the increase in densities after producing $\mathrm{Cu}_{6} \mathrm{Sn}_{5}$ and $\mathrm{Cu}_{3} \mathrm{Sn}$ [23-26]. And this shrinkage is constrained by the attachment to adjacent substrate and solder, which ultimately results in development of stress within IMC layer [27]. So, it is highly likely that the observed evolution of hardness and Young's modulus of $\mathrm{Cu}_{6} \mathrm{Sn}_{5}$ and $\mathrm{Cu}_{3} \mathrm{Sn}_{\mathrm{s}}$ a result of volume shrinkage.

In nanoindentation, there is a constant ratio between hardness and tensile strength from Tabor's model [28, 29],

$$
H=3 \sigma_{\mathrm{UTS}}
$$

where $\sigma_{\mathrm{UTS}}$ is ultimate tensile strength (UTS), $H$ is Vickers hardness.

In Fig. 5, the measured highest drop in hardness are $3.6 \mathrm{GPa}$ for $\mathrm{Cu}_{6} \mathrm{Sn}_{5}$ (sample after aging for 100h and $200 \mathrm{~h}$ ) and $2.2 \mathrm{GPa}$ for $\mathrm{Cu}_{3} \mathrm{Sn}$ (samples after aging for $100 \mathrm{~h}$ and $300 \mathrm{~h}$ ), respectively. Therefore, the induced change in UTS and corresponding tensile strain can be estimated as $\Delta \sigma_{\mathrm{Cu} 6 \mathrm{Sn} 5}=-1.2 \mathrm{GPa}$ and $\Delta \varepsilon_{\mathrm{Cu} 6 \mathrm{Sn} 5}=-0.011$ for $\mathrm{Cu}_{6} \mathrm{Sn}_{5}$, and $\Delta \sigma_{\mathrm{Cu} 3 \mathrm{Sn}}=0.7 \mathrm{GPa}$ and $\Delta \varepsilon_{\mathrm{Cu} 3 \mathrm{Sn}}=-0.005$ for $\mathrm{Cu}_{3} \mathrm{Sn}$, where negative values indicate a drop in corresponding parameters. Given the fact that UTS and tensile fracture strain for a specific material is usually constant at room temperature, this drop in stress and strain is owing to different strain states (or start point of $\sigma-\varepsilon$ curve) of the two samples in comparison. Therefore, it is reasonable to conclude that the experimental maximum tensile strain 
induced by volume shrinkage are $\varepsilon_{\mathrm{Cu} 6 \mathrm{Sn} 5}=0.011$ and $\varepsilon_{\mathrm{Cu} 3 \mathrm{Sn}}=0.005$.

Based on different densities of $\mathrm{Cu}, \mathrm{Sn}, \mathrm{Cu}_{6} \mathrm{Sn}_{5}$ and $\mathrm{Cu}_{3} \mathrm{Sn}$, theoretical tensile strains along one direction caused by volume shrinkage are 0.017 and 0.126 for $\mathrm{Cu}_{6} \mathrm{Sn}_{5}$ and $\mathrm{Cu}_{3} \mathrm{Sn}$, respectively [23]. It can be found that tensile strain by volume shrinkage for $\mathrm{Cu}_{6} \mathrm{Sn}_{5}$ in this work is close to theoretical value, while there is a notable difference between the two values for $\mathrm{Cu}_{3} \mathrm{Sn}$.

However, it should be noticed that numerical analysis on tensile strain by volume shrinkage is based on calculation without any account of the material. From literatures, because of microstructural evolution, volume shrinkage induced by $\mathrm{Cu}-\mathrm{Sn}$ interfacial reactions in aging does not necessarily fully convert to tension stress within IMCs. It has been reported that volume shrinkage can be relieved by formation of voids within IMCs in $\mathrm{Ni}-\mathrm{Sn}$ and $\mathrm{Cu}-\mathrm{Sn}$ system [30, 31]. Besides, formation of Kirkendall voids [32] close to $\mathrm{Cu}_{3} \mathrm{Sn} / \mathrm{Cu}$ interface can also significantly attenuate the constraint and lower the stress level within $\mathrm{Cu}_{3} \mathrm{Sn}$ because of resultant discontinuity in microstructure.

For Young's modulus, from equation 2 and equation 3, there is no direct correlation between stress and elastic modulus. However, a higher Young's modulus is a result of higher contact stiffness, which means the drop in load is more evident when indenter withdraws the same depth. This process is dominated by resistant stress from sample and increase of tension stress within IMC layer can surely lower it. Consequently, ascension in tension stress within tested sample can reduce measured Young's modulus in nanoindentation tests. Similar phenomenon has also been reported by other researchers in tests on other materials [33-35].

Therefore, both measured hardness and Young's modulus is related to the stress state within IMC layer, and these two parameters reached the bottom after the same aging duration for both $\mathrm{Cu}_{6} \mathrm{Sn}_{5}$ and $\mathrm{Cu}_{3} \mathrm{Sn}$, as illustrated in Fig. 5 and Fig. 6. The followed slight increase can probably be a result of microstructural evolution. Build-up of stress can be partly relieved by formation of voids. And, interstitial diffusion of $\mathrm{Cu}$ in $\mathrm{Sn}$ and the diffusion in reverse direction can turn the initial tension stress to compressive stress during isothermal aging [27]. Therefore, with longer aging, tension stress within IMC layers fell gradually, and measured hardness and Young's modulus slightly ascended.

For hardness and Young's modulus of $\mathrm{Cu}$, both parameters evolved in reverse trend in comparison to those of $\mathrm{Cu}_{3} \mathrm{Sn}$. This is probably due to the mutual constraint between $\mathrm{Cu}_{3} \mathrm{Sn}$ and $\mathrm{Cu}$. And microstructural recovery of $\mathrm{Cu}$ can also contribute to the fall of its hardness and Young's modulus after they peaked at $200 \mathrm{~h}$.

Since failures of interconnections are frequently located within $\mathrm{Cu}_{6} \mathrm{Sn}_{5}$ and $\mathrm{Cu}_{3} \mathrm{Sn}$ layers, this U-shape evolution of mechanical properties of interlayers implies that there is probably a sensitive aging duration for $\mathrm{Sn}$ - 
based solder/Cu solder joints. To be more specific, after aging for a certain period, Sn-based solder/Cu solder joints should be more prone to fail under tensile load because of the ascension of tensile stress resulted from volume shrinkage within IMC layer.

\section{Conclusions}

The hardness and Young's moduli of the interfacial $\mathrm{Cu}_{6} \mathrm{Sn}_{5}$ layer, $\mathrm{Cu}_{3} \mathrm{Sn}$ layer and $\mathrm{Cu}$ substrate in $\mathrm{Sn} 99 \mathrm{Cu} 1 / \mathrm{Cu}$ solder joints were evaluated using nanoindentation tests after $0-500 \mathrm{~h}$ of ageing. Our conclusions based on the presented results and discussion are as follows:

1. Throughout the ageing at $175^{\circ} \mathrm{C}$, the average hardness of the interlayers was $4.6 \pm 2.0 \mathrm{GPa}$ for $\mathrm{Cu}_{6} \mathrm{Sn}_{5}$, $5.9 \pm 1.1 \mathrm{GPa}$ for $\mathrm{Cu}_{3} \mathrm{Sn}$ and $1.6 \pm 0.1 \mathrm{GPa}$ for $\mathrm{Cu}$.

2. After the solder joints were aged for progressively increasing durations, the average Young's moduli of the different interlayers were $109 \pm 28 \mathrm{GPa}$ for $\mathrm{Cu}_{6} \mathrm{Sn}_{5}, 146 \pm 9 \mathrm{GPa}$ for $\mathrm{Cu}_{3} \mathrm{Sn}$ and $150 \pm 16 \mathrm{GPa}$ for $\mathrm{Cu}$.

3. The hardness and Young's moduli for $\mathrm{Cu}_{6} \mathrm{Sn}_{5}$ and $\mathrm{Cu}_{3} \mathrm{Sn}$ layers evolved similarly. These parameters reached the lowest point after aging for $200 \mathrm{~h}$ for $\mathrm{Cu}_{6} \mathrm{Sn}_{5}$ and $300 \mathrm{~h}$ for $\mathrm{Cu}_{3} \mathrm{Sn}$, followed by a slight ascension. This U-shape evolution can be attributed to increase in tensile stress within IMC layer induced by volume shrinkage in solid-state reactions.

4. Throughout ageing, Young's modulus and hardness of $\mathrm{Cu}$ generally evolved in a reverse trend in comparison to those of $\mathrm{Cu}_{3} \mathrm{Sn}$, though fluctuations in hardness of $\mathrm{Cu}$ was within smaller range. The opposite evolution in mechanical properties of the two adjacent layers was a result of mutual constraint and volume shrinkage in IMC.

\section{Acknowledgements}

This research was supported by a Marie Curie International Research Staff Exchange Scheme Project within the 7th European Community Framework Programme, No. PIRSES-GA-2010-269113, entitled "Micro-MultiMaterial Manufacture to Enable Multifunctional Miniaturised Devices (M6)," the National Natural Science Foundation of China (No: 60976076), and a China-European Union technology cooperation project, No. 1110. The authors also acknowledge the open funding via State Key Laboratory of Materials Processing and Die \& Mould Technology (No: P2018-018). 


\section{References}

[1] S. Ahat, M. Sheng, and L. Luo, J. Electron. Mater. 30, 10 (2001).

[2] Y. C. Chan, A. C. K. So, and J. K. L. Lai, Mater. Sci. Eng. B-Adv. 55, 1-2 (1998).

[3] M. Date, T. Shoji, M. Fujiyoshi, K. Sato, and K. N. Tu, Scripta Mater. 51, 7 (2004).

[4] J. Y. Kim, J. Yu, and S. H. Kim, Acta Mater. 57, 17 (2009).

[5] I. Shohji, T. Nakamura, F. Mori, and S. Fujiuchi, Mater. Trans. 43, 8 (2002).

[6] A. K. Gain, Y. C. Chan, and W. K. C. Yung, Microelectron. Reliab. 51, 5 (2011).

[7] G.-Y. Jang, J.-W. Lee, and J.-G. Duh, J. Electron. Mater. 33, 10 (2004).

[8] P.-F. Yang, Y.-S. Lai, S.-R. Jian, J. Chen, and R.-S. Chen, Mater. Sci. Eng. A-Struct. 485, 1-2 (2008).

[9] D. Mu, H. Huang, and K. Nogita, Mater. Lett. 86, (2012).

[10] L. Shen, P. Lu, S. Wang, and Z. Chen, J. Alloy Compd. 574, (2013).

[11] T. Chudoba and F. Richter, Surf. Coat. Tech. 148, 2-3 (2001).

[12] K. O. Kese, Z. C. Li, and B. Bergman, J. Mater. Res. 19, 10 (2004).

[13] W. Wang and K. Lu, J. Mater. Res. 17, 9 (2002).

[14] W. C. Oliver and G. M. Pharr, J. Mater. Res. 7, 6 (1992).

[15] S. Lotfian, J. M. Molina-Aldareguia, K. E. Yazzie, J. Llorca, and N. Chawla, J. Electron. Mater. 42, 6 (2013).

[16] S. Carlsson and P. L. Larsson, Acta Mater. 49, 12 (2001).

[17] S. Carlsson and P. L. Larsson, Acta Mater. 49, 12 (2001).

[18] J. G. Swadener, B. Taljat, and G. M. Pharr, J. Mater. Res. 16, 7 (2001).

[19] Y.-H. Lee and D. Kwon, J. Mater. Res. 17, 4 (2002).

[20] T. Y. Tsui, W. C. Oliver, and G. M. Pharr, J. Mater. Res. 11, 3 (1996).

[21] A. Bolshakov, W. C. Oliver, and G. M. Pharr, J. Mater. Res. 11, 3 (1996).

[22] S. Suresh and A. E. Giannakopoulos, Acta Mater. 46, 16 (1998).

[23] Z. Chen, C. Liu, Y. Wu, B. An, and L. Zhou, J. Electron. Mater. 44, 11 (2015).

[24] P. L. Tu, Y. C. Chan, K. C. Hung, and J. K. L. Lai, IEEE Trans. Adv. Pack. 23, 4 (2000).

[25] B. Y. Wu, H. W. Zhong, Y. C. Chan, and M. O. Alam, J. Mater. Sci.-Mater. El. 17, 11 (2006).

[26] C.-B. Lee, S.-B. Jung, Y.-E. Shin, and C.-C. Shur, Mater. Trans. 43, 8 (2002).

[27] J. Y. Song, J. Yu, and T. Y. Lee, Scripta Mater. 51, 2 (2004).

[28] P. Zhang, S. X. Li, and Z. F. Zhang, Mater. Sci. Eng. A-Struct. 529, (2011). 
[29] I. M. Hutchings, J. Mater. Res. 24, 3 (2009).

[30] C. C. Li, C. K. Chung, W. L. Shih, and C. R. Kao, Metall. and Mat. Trans. A, 45, 5 (2014).

[31] S. J. Wang, L. H. Hsu, N. K. Wang, and C. E. Ho, J. Electron. Mater. 43, 1 (2014).

[32] D. Kim, J.-h. Chang, J. Park, and J. J. Pak, J. Mater. Sci: Mater. Electron. 22, 7 (2011).

[33] K. Yamaguchi, H. Adachi, and N. Takakura, Met. Mater. 4, 3 (1998).

[34] S. L. Bazhenov, A. K. Rogozinskii, S. S. Evstiforov, and A. A. Berlin, Dolk. Phys. Chem. 3433, 2 (2010).

[35] J. A. Benito, J. Jorba, J. M. Manero, and A. Roca, Metall. Mater. Trans. A, 36A, (2005). 


\section{Captions of figures}

Fig. 1 Schematic of designated locations for nanoindents in solder joints.

Fig. 2 Nanoindents in (a) $\mathrm{Cu}_{6} \mathrm{Sn}_{5}$ layer, (c) $\mathrm{Cu}_{3} \mathrm{Sn}$ layer and (e) Cu substrate. Sub-figures (b), (d), (f) show the respective 3D profiles of indents in corresponding layers.

Fig. 3 Surface profiles across the centre of nanoindents within (a) $\mathrm{Cu}_{6} \mathrm{Sn}_{5}$ layer, (b) $\mathrm{Cu}_{3} \mathrm{Sn}_{\text {layer }}$ and (c) $\mathrm{Cu}$ substrate.

Fig. 4 Representative load-displacement curves from nanoindents in $\mathrm{Cu}_{6} \mathrm{Sn}_{5}$ layer, $\mathrm{Cu}_{3} \mathrm{Sn}$ layer and $\mathrm{Cu}$ substrate.

Fig. 5 Evolution of hardness within (a) $\mathrm{Cu}_{6} \mathrm{Sn}_{5}$ layer, (b) $\mathrm{Cu}_{3} \mathrm{Sn}$ layer and (c) $\mathrm{Cu}$ substrate.

Fig. 6 Evolution of Young's moduli within (a) $\mathrm{Cu}_{6} \mathrm{Sn}_{5}$ layer, (b) $\mathrm{Cu}_{3} \mathrm{Sn}$ layer and (c) $\mathrm{Cu}$ substrate. 


\section{Captions of tables}

Table 1 Parameters and settings for nanoindentation tests.

Table 2 Comparison between the hardness obtained in this work and reported results.

Table 3 Comparison between Young's moduli in this work and reported results. 


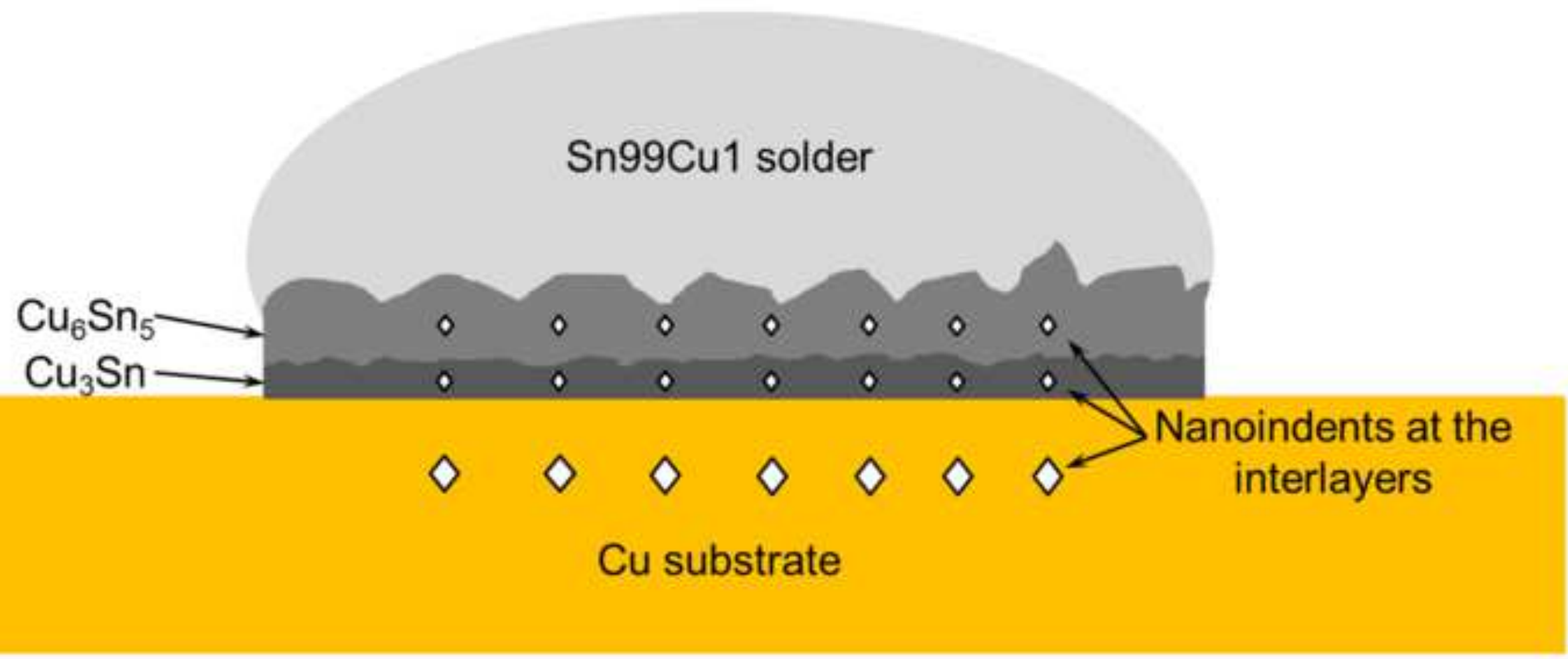



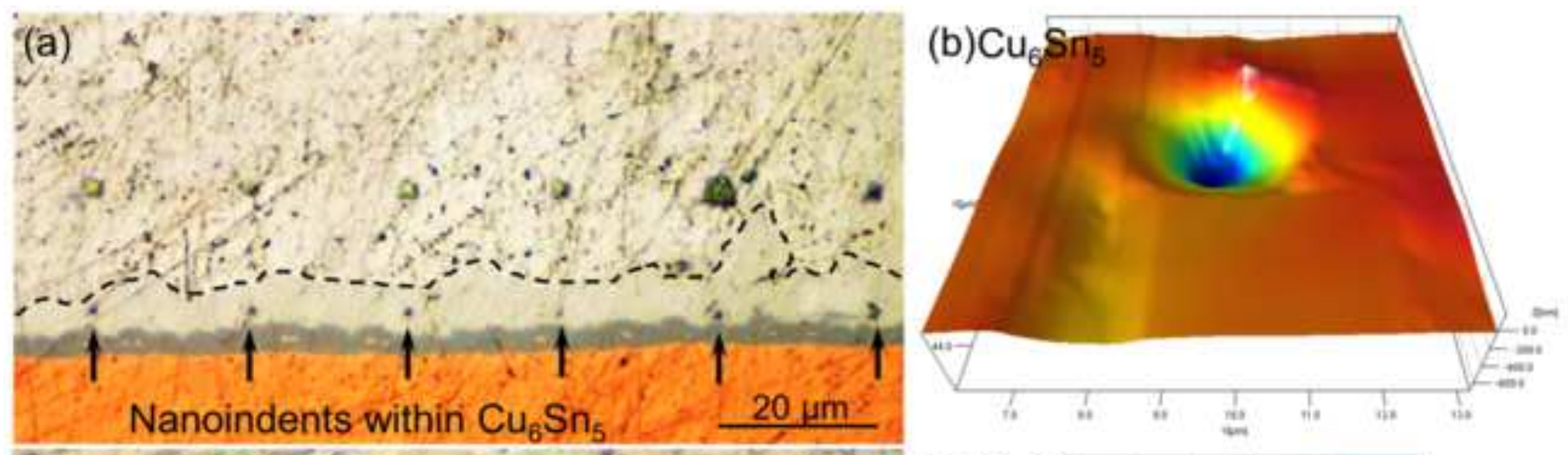

(c) stipure
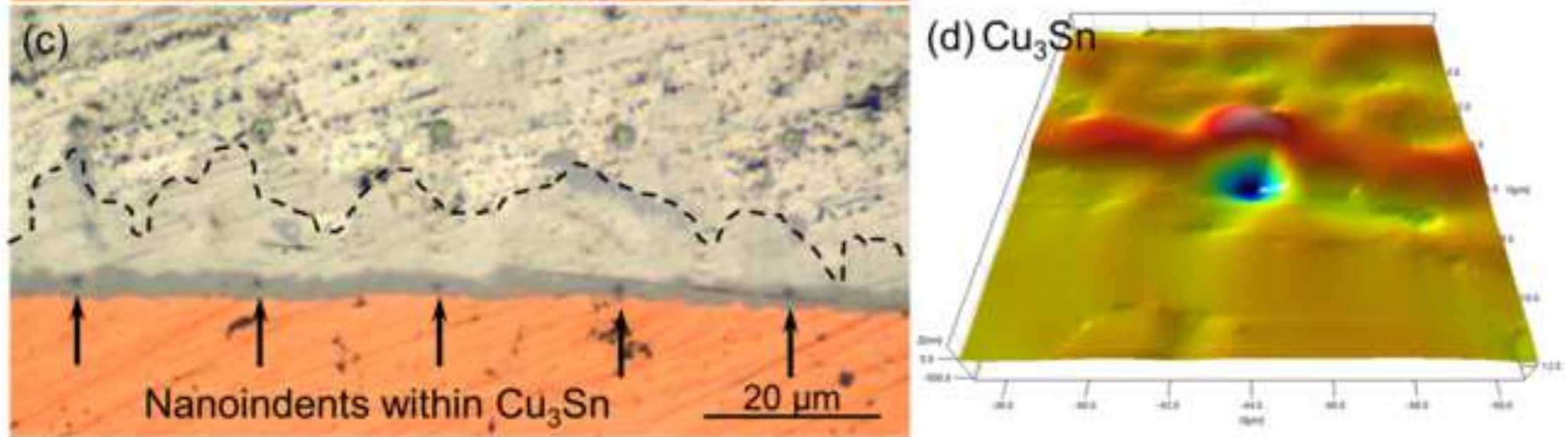

(e)
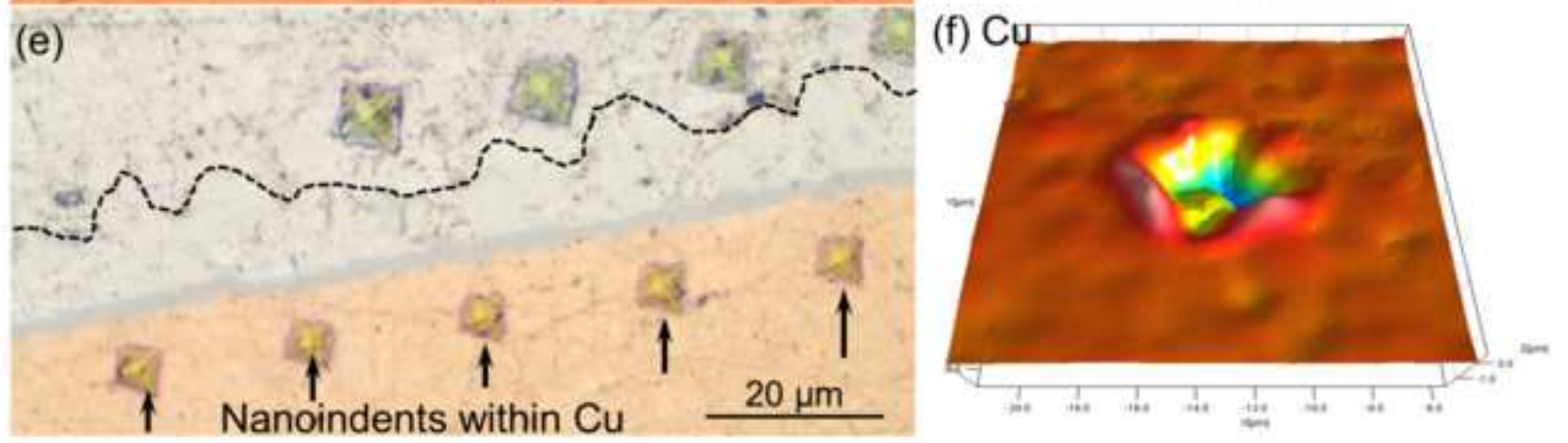

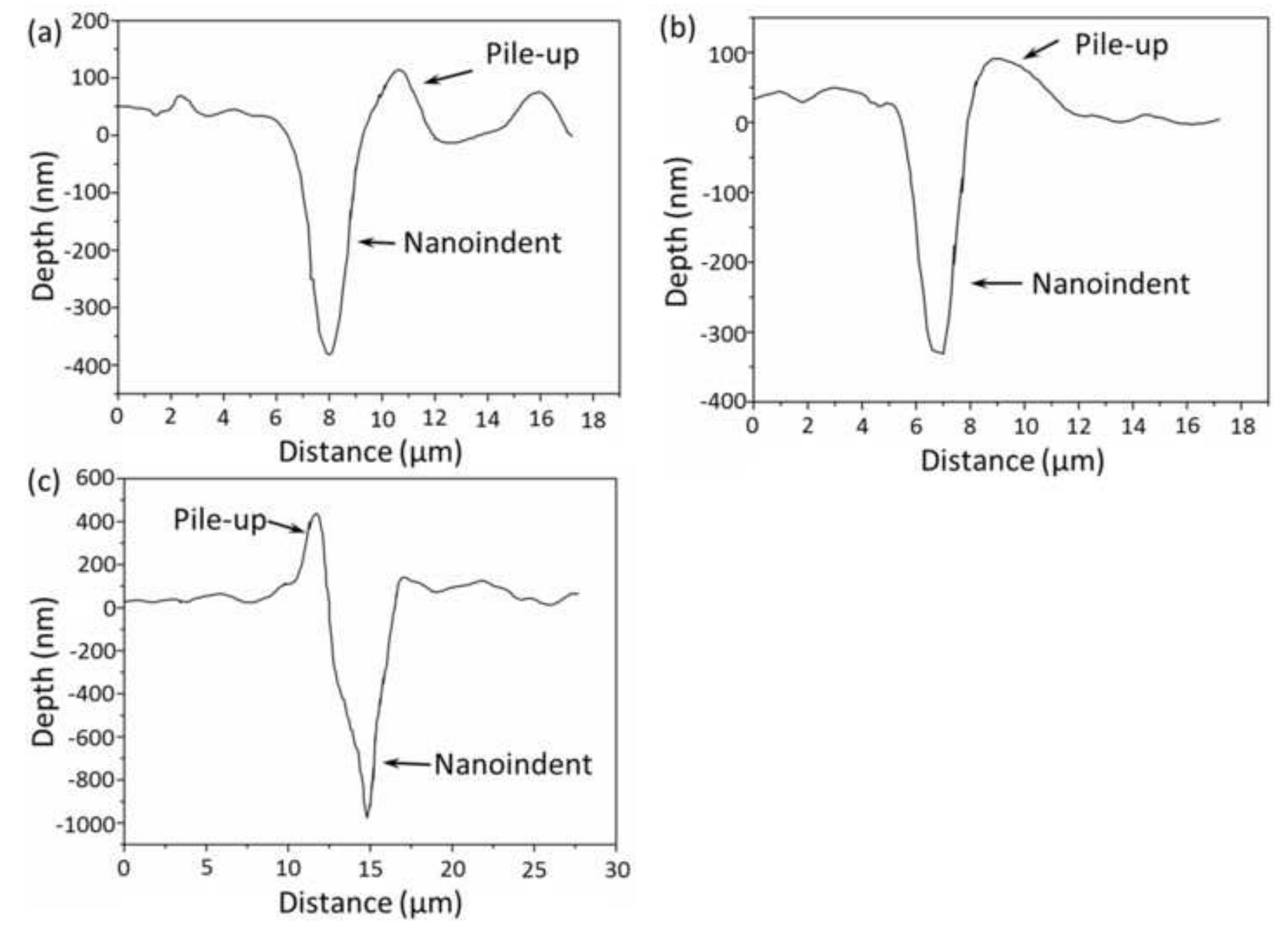

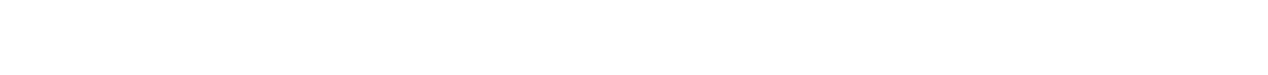




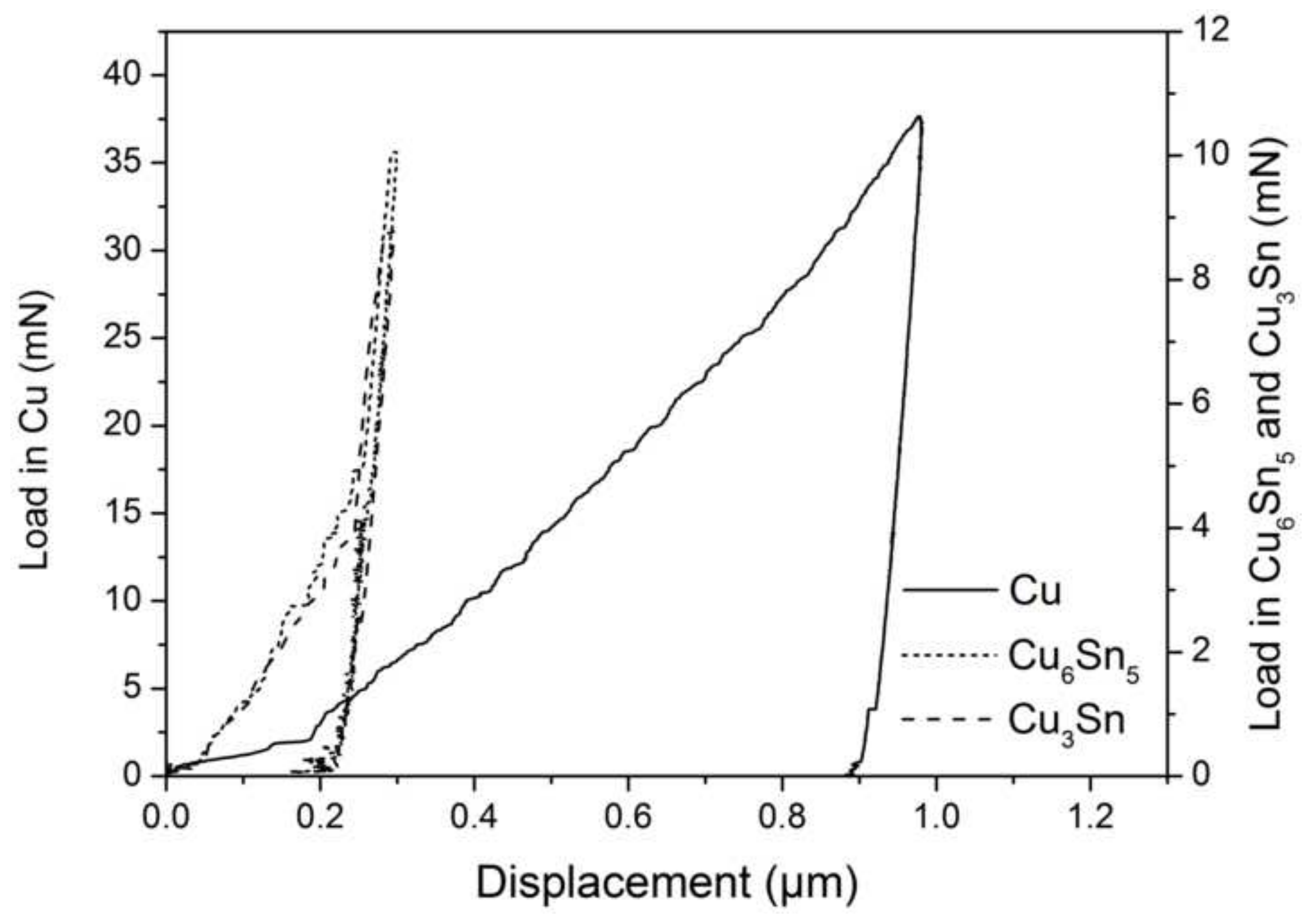


Click here to download Figure Fig. 5.TIF $\underline{\underline{ }}$
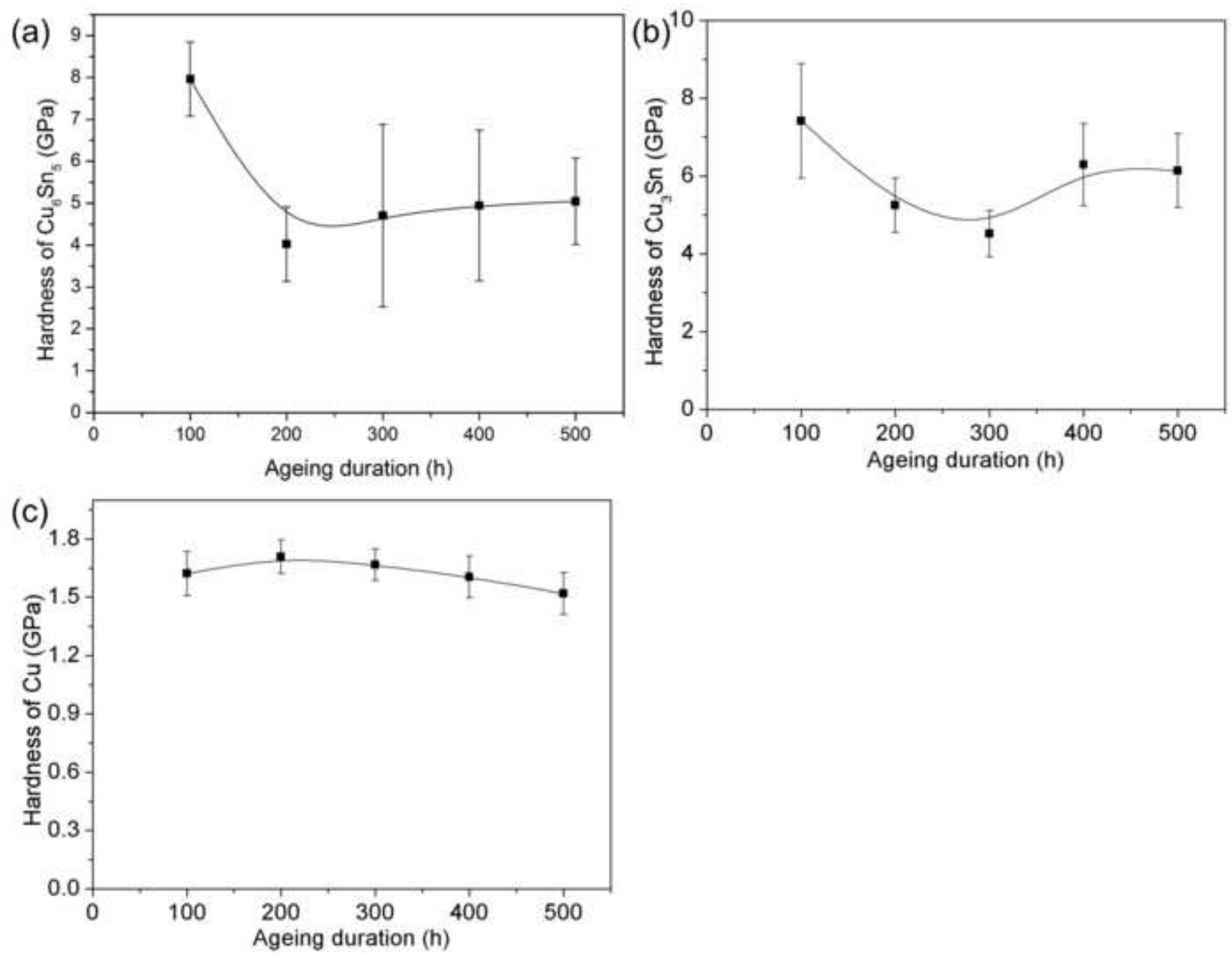
Click here to download Figure Fig. 6.TIF $\underline{\underline{ }}$
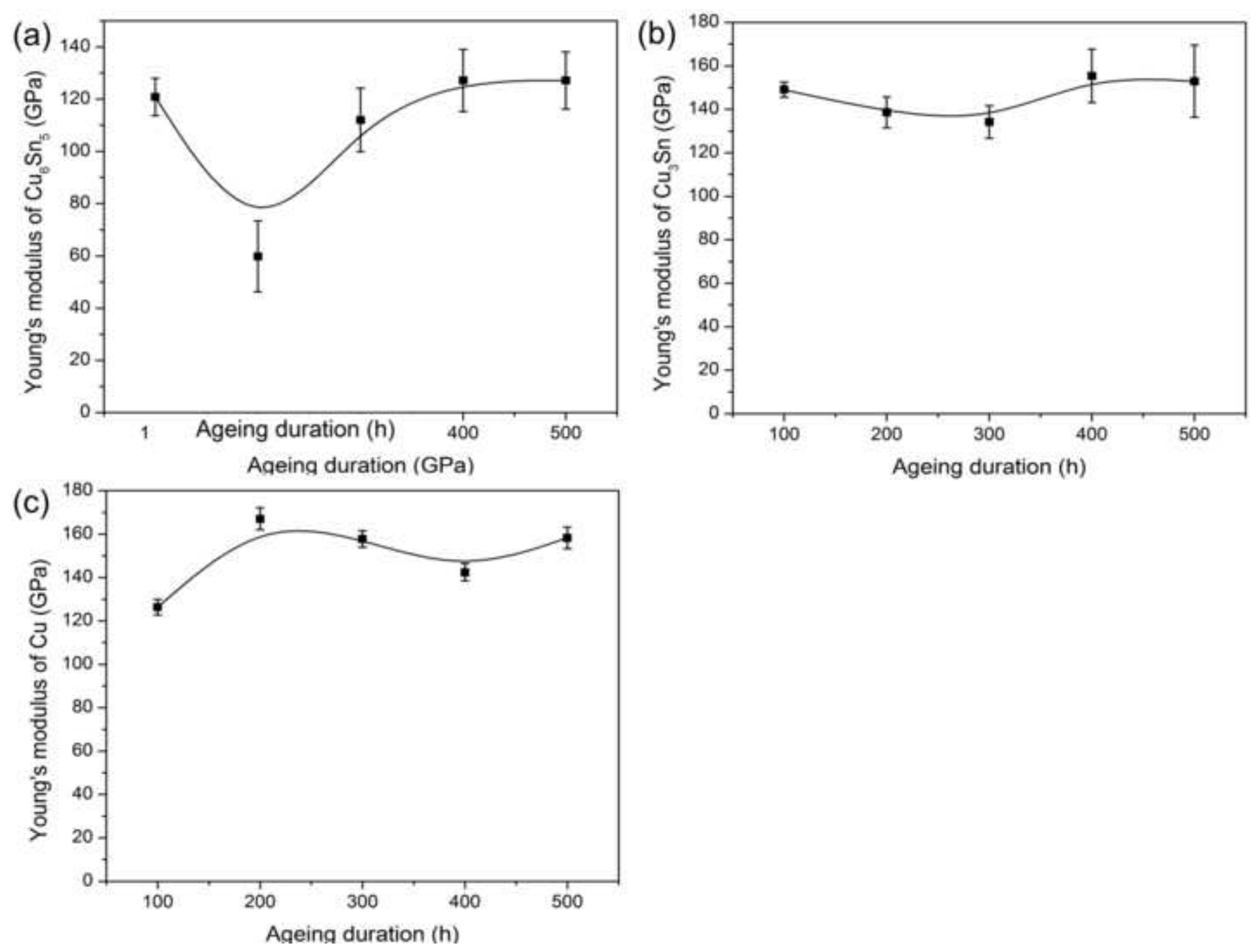
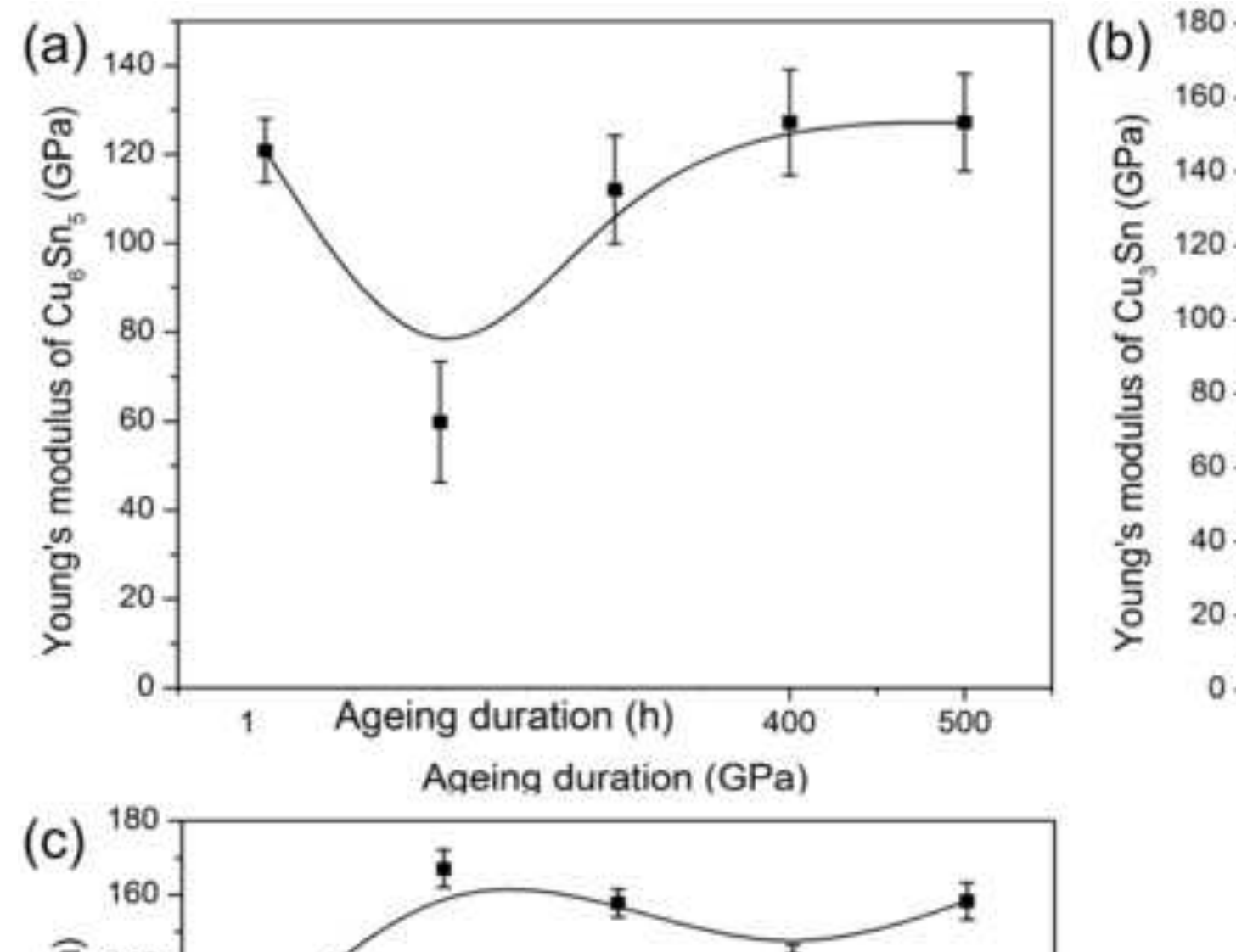


\begin{tabular}{ccccc} 
Specimen & Maximum Depth & Termination & Loading rate & Unloading rate \\
\hline $\mathrm{Cu}$ & $1 \mu \mathrm{m}$ & Depth control & $1 \mathrm{mN} / \mathrm{s}$ & $1 \mathrm{mN} / \mathrm{s}$ \\
$\mathrm{Cu}_{6} \mathrm{Sn}_{5}$ & $0.3 \mu \mathrm{m}$ & Depth control & $0.2 \mathrm{mN} / \mathrm{s}$ & $0.2 \mathrm{mN} / \mathrm{s}$ \\
$\mathrm{Cu}_{3} \mathrm{Sn}$ & $0.3 \mu \mathrm{m}$ & Depth control & $0.4 \mathrm{mN} / \mathrm{s}$ & $0.4 \mathrm{mN} / \mathrm{s}$ \\
\hline
\end{tabular}




\section{Average hardness after ageing (GPa)}

\section{Reported hardness (GPa)}

$\begin{array}{ccc}\mathrm{Cu}_{6} \mathrm{Sn}_{5} & 4.9 \pm 1.8 & 6.1 \pm 0.5[7] \\ \mathrm{Cu}_{3} \mathrm{Sn} & 5.9 \pm 1.1 & 5.7 \pm 0.6[7] \\ & & \\ \mathrm{Cu} & 1.6 \pm 0.1 & 2.2 \pm 0.2[7]\end{array}$




\section{Average $\mathrm{E}$ after ageing (GPa)}

\section{Reported E (GPa)}
$\mathrm{Cu}_{6} \mathrm{Sn}_{5}$
$109.4 \pm 28.4$
$125 \pm 6.8[7]$
$\mathrm{Cu}_{3} \mathrm{Sn}$
$146.0 \pm 9.2$
$135.7 \pm 5.9[7]$
$\mathrm{Cu}$
$150.4 \pm 16.1$
$110.8 \pm 3.8[7]$ 